\title{
Correction to: The computational framework for continuum-kinematics-inspired peridynamics
}

\author{
A. Javili ${ }^{1}$ - S. Firooz ${ }^{1}$ - A. T. McBride ${ }^{2}$ - P. Steinmann ${ }^{2,3}$
}

Published online: 3 September 2020

(c) The Author(s) 2020

\section{Correction to: Computational Mechanics https://doi.org/10.1007/s00466-020-01885-3}

The article "The computational framework for continuumkinematics-inspired peridynamics", written by "A. Javili, S. Firooz, A. T. McBride and P. Steinmann", was originally published electronically on the publisher's internet portal on 30 July 2020 without open access. With the author(s)' decision to opt for Open Choice the copyright of the article changed on 13 August 2020 to (C) The Author(s) 2020 and the article is forthwith distributed under a Creative Commons Attribution 4.0 International License (https://creativecommons.org/ licenses/by/4.0/), which permits use, sharing, adaptation, distribution and reproduction in any medium or format, as long as you give appropriate credit to the original author(s) and the source, provide a link to the Creative Commons licence, and indicate if changes were made.

The original article has been corrected.

The original article can be found online at https://doi.org/10.1007/s00 466-020-01885-3.

$\triangle$ A. Javili

ajavili@bilkent.edu.tr

1 Department of Mechanical Engineering, Bilkent University, 06800 Ankara, Turkey

2 Glasgow Computational Engineering Centre, James Watt School of Engineering, University of Glasgow, Glasgow G12 8QQ, UK

3 Chair of Applied Mechanics, University of Erlangen-Nuremberg, Egerland Str. 5, 91058 Erlangen, Germany
The images or other third party material in this article are included in the article's Creative Commons licence, unless indicated otherwise in a credit line to the material. If material is not included in the article's Creative Commons licence and your intended use is not permitted by statutory regulation or exceeds the permitted use, you will need to obtain permission directly from the copyright holder. To view a copy of this licence, visit http://creativecommons.org/licenses/by/4.0.

Open Access This article is licensed under a Creative Commons Attribution 4.0 International License, which permits use, sharing, adaptation, distribution and reproduction in any medium or format, as long as you give appropriate credit to the original author(s) and the source, provide a link to the Creative Commons licence, and indicate if changes were made. The images or other third party material in this article are included in the article's Creative Commons licence, unless indicated otherwise in a credit line to the material. If material is not included in the article's Creative Commons licence and your intended use is not permitted by statutory regulation or exceeds the permitted use, you will need to obtain permission directly from the copyright holder. To view a copy of this licence, visit http://creativecomm ons.org/licenses/by/4.0/.

Publisher's Note Springer Nature remains neutral with regard to jurisdictional claims in published maps and institutional affiliations. 